\title{
SOCIAL DIMENSION OF THE EUROPEAN HIGHER EDUCATION AREA: TENDENCIES OF DEVELOPMENT OF NORMATIVE, THEORETICAL AND ORGANIZATIONAL BASES
}

\begin{abstract}
Alina Sbruieva
INTRODUCTION

The urgency of forming the European Higher Education Area (EHEA) is driven by economic, technological and social factors. To the first two groups of factors (economic and technological) we refer, first of all, globalization and regionalization (Europeanization) of economic development, development of ICT and knowledge society, which turn higher education into a significant lever for ensuring the competitiveness of the region.

It should be noted that construction of the regional education area should solve the task of training highly skilled labor force, which is competitive in the regional and global labor markets.

Integration processes in the field of European higher education are also intended to contribute to the sustainable development of the region by training professionals in order to be productive, to continue to learn, to solve problems, to be creative, to live together and with nature in peace and harmony.
\end{abstract}

At the same time, we consider Europeanization as a social factor in building a regional higher education area in the context of realizing the idea of the Social Europe based on democratic values of equal civil rights, opportunities and social equity. Taking into account the relevance of implementation of the social priorities of European society in the EHEA has led to emergence in the context of the Bologna process of the so-called social dimension of reforms, which did not become sufficiently clear and concretized at the first stages of implementation of changes in higher education.

And only later, under the influence of the most interested stakeholders in the process of educational change - the student body, the social dimension of the reforms receive support in the reform documents along with such priorities as quality, mobility, comparability of input and learning outcomes.

The subject of our consideration has been the social dimension of reforms within the Bologna Process, the responsibility for which is increasingly recognized by the European political and academic community, by European society as a whole. 
The sources of our research are official documents of the Bologna Process, namely the communiqués and declarations of conferences of Ministers of Education of the Bologna member states; political and analytical documents of international stakeholder organizations in the sphere of higher education; research works of economists, sociologists and political scientists studying the problems of state responsibility for the development of higher education; research works of education reform theorists; materials and final reports of EU (Erasmus) projects exploring different aspects of the social dimension of higher education in the European region.

\section{Retrospection of the formation of normative bases of the EHEA social dimension}

The statement of the need to ensure the social dimension of the European Higher Education Area was first voiced at a conference of Ministers of Education of the Bologna Club Members in Prague (2001). However, according to the researchers of the process of establishing the EHEA, in particular P. Zgaga ${ }^{1}$ and M. Klemenčič ${ }^{2}$, emergence of the Prague Conference formulations was preceded by active discussions about on the investigated problem with representatives of student organizations. The student body has been the most persistent in demanding that reforms should be given the social dimension and making this dimension one of the priorities of the Bologna reforms.

In the pre-Prague period, the student organization ESIB developed and presented for discussion of the representatives of the Bologna Club countries the document "The Student Göteborg Convention"3. The ideas of this document were taken into account and even formed the basis for the interpretation of the social dimension of higher education at the Prague Summit of Ministers of Education. In a summit document, the Prague Communiqué, it was stated that the foreseen reforms of higher education systems would be aimed at enhancing social cohesion, reducing the level of social injustice in education; promoting full realization of the individual's potential for the benefit of each individual and social and economic development of society as a whole.

${ }^{1}$ Zgaga, P. (2015). The social dimension in the European Higher Education Area. In Baranović, B. (Ed.), Koji srednješkolci namjeravaju studirati? Pristup visokom obrazovanju $i$ odabir studija [Which high school students plan to study? Access to higher education and the selection of studies]. (Biblioteka Znanost i društvo, 37). Zagreb: Institut za društvena istraživanja, pp. 211-233.

${ }^{2}$ Klemenčič, M. (2012). How ESIB got into the Bologna Process. In ESU turns 30! Fighting for student rights since 1982. Brussels: ESU, pp. 17-28.

${ }^{3}$ ESIB (2001). Student Göteborg Declaration (25 March 2001). The Student Göteborg Convention, 22nd to the 25th of March 2001. 
A more accurate understanding of the social dimension of higher education can be found in the Communique of the Conference of Ministers of Higher Education of Europe, adopted in Berlin in 2003. Ministers attending the Berlin Conference reaffirmed the importance of the social dimension of the Bologna Process. It was recognized that the need to enhance the competitiveness of European higher education should be balanced by improving the social characteristics of the EHEA, which would further enhance social cohesion and reduce social and gender inequalities, both at the national and European level. In this context, the Ministers reaffirmed their position that higher education was a public good and a social responsibility.

In most of the subsequent documents of the Bologna Process (from the Bergen Communiqué 2005 to the Paris Communiqué 2018), the characteristics of the social dimension of European higher education were highlighted in separate sections. In order to clarify the analysis of the texts of the Bologna documents, we will outline provisions in the form of a chronological table.

Table 1

\section{The social dimension of the EHEA in the texts} of the basic documents of the Bologna Process

\begin{tabular}{|c|c|}
\hline Document & Interpretation of the notion of the EHEA social dimension \\
\hline $\begin{array}{l}\text { The Prague } \\
\text { Communiqué } \\
(2001)^{4}\end{array}$ & $\begin{array}{l}\text { Ministers also reaffirmed the need, recalled by students, to take } \\
\text { account of the social dimension in the Bologna Process. They } \\
\text { (Ministers) support the idea that higher education (HEd) should be } \\
\text { considered a public good and is and will remain a public responsibility } \\
\text { (regulations etc.), and that students are full members of the higher } \\
\text { education community. Lifelong learning strategies are necessary to } \\
\text { face the challenges of competitiveness and the use of new technologies } \\
\text { and to improve social cohesion, equal opportunities and the quality of } \\
\text { life }\end{array}$ \\
\hline $\begin{array}{l}\text { The Berlin } \\
\text { Communiqué } \\
(2003)^{5}\end{array}$ & $\begin{array}{l}\text { Ministers stress the need for appropriate studying and living conditions } \\
\text { for the students, so that they can successfully complete their studies } \\
\text { within an appropriate period of time without obstacles related to their } \\
\text { social and economic background. They also stress the need for more } \\
\text { comparable data on the social and economic situation of students. They } \\
\text { stress the need to improve opportunities for all citizens, in accordance } \\
\text { with their aspirations and abilities, to follow the lifelong learning paths } \\
\text { into and within HEd }\end{array}$ \\
\hline
\end{tabular}

${ }^{4}$ Towards the European Higher Education Area. Communiqué of the meeting of European Ministers in charge of Higher Education in Prague on May 19th 2001. Retrieved from: www.ehea.info/Uploads/Declarations/PRAGUE_COMMUNIQUÉ.pdf

${ }^{5}$ Berlin Communiqué (2003). Realizing the European Higher Education Area. EHEA Ministerial Conference, Berlin, 19, September, 2003. Retrieved from: https:// www.ehea.info/page-ministerial-declarations-and-communiques. 


\begin{tabular}{|c|c|}
\hline $\begin{array}{l}\text { The Bergen } \\
\text { Communiqué } \\
(2005)^{6}\end{array}$ & $\begin{array}{l}\text { The social dimension of the Bologna Process is a constituent part of } \\
\text { the EHEA and a necessary condition for the attractiveness and } \\
\text { competitiveness of the EHEA. We therefore renew our commitment to } \\
\text { making quality HEd equally accessible to all, and stress the need for } \\
\text { appropriate conditions for students so that they can complete their } \\
\text { studies without obstacles related to their social and economic } \\
\text { background. The social dimension includes measures taken by } \\
\text { governments to help students, especially from socially disadvantaged } \\
\text { groups, in financial and economic aspects and to provide them with } \\
\text { guidance and counselling services with a view to widening access }\end{array}$ \\
\hline $\begin{array}{l}\text { The London } \\
\text { Communiqué } \\
(2007)^{7}\end{array}$ & $\begin{array}{l}\text { HEd should play a strong role in fostering social cohesion, reducing } \\
\text { inequalities and raising the level of knowledge, skills and competences } \\
\text { in society. Policy should therefore aim to maximise the potential of } \\
\text { individuals in terms of their personal development and their } \\
\text { contribution to a sustainable and democratic knowledge-based society. } \\
\text { We share the societal aspiration that the student body entering, } \\
\text { participating in and completing HEd at all levels should reflect the } \\
\text { diversity of our populations. We reaffirm the importance of students } \\
\text { being able to complete their studies without obstacles related to their } \\
\text { social and economic background. We therefore continue our efforts to } \\
\text { provide adequate student services, create more flexible learning } \\
\text { pathways into and within HEd, and to widen participation at all levels } \\
\text { on the basis of equal opportunity }\end{array}$ \\
\hline $\begin{array}{l}\text { The Leuven } \\
\text { and Louvain- } \\
\text { la-Neuve } \\
\text { Communiqué } \\
(2009)^{8}\end{array}$ & $\begin{array}{l}\text { The student body within HEd should reflect the diversity of Europe's } \\
\text { populations. We therefore emphasize social characteristics of HEd and } \\
\text { aim to provide equal opportunities to quality education. Access into } \\
\text { HEd should be widened by fostering the potential of students from } \\
\text { underrepresented groups and by providing adequate conditions for the } \\
\text { completion of their studies. This involves improving the learning } \\
\text { environment, removing all barriers to study, and creating the } \\
\text { appropriate economic conditions for students to be able to benefit from } \\
\text { the study opportunities at all levels. Each participating country will set } \\
\text { measurable targets for widening overall participation and increasing } \\
\text { participation of underrepresented groups in higher education, to be } \\
\text { reached by the end of the next decade. Efforts to achieve equity in HEd } \\
\text { should be complemented by actions in other parts of the educational } \\
\text { system }\end{array}$ \\
\hline $\begin{array}{l}\text { The Budapest- } \\
\text { Vienna }\end{array}$ & $\begin{array}{l}\text { We commit ourselves, notwithstanding these difficult economic times, } \\
\text { to ensuring that }\end{array}$ \\
\hline
\end{tabular}

${ }^{6}$ Bergen Communiqué (2005). The European Higher Education Area - Achieving the Goals. Communiqué of the Conference of European Ministers Responsible for Higher Education, Bergen, 19-20 May 2005. Retrieved from: https:// www.ehea.info/page-ministerialdeclarations-and-communiques

${ }^{7}$ London Communiqué (2007). Towards the European Higher Education Area: responding to challenges in a globalised world. EHEA Ministerial Conference, London, 18-19 May, 2007. Retrieved from https:// www.ehea.info/page-ministerial-declarations-and-communiques

${ }^{8}$ Leuven and Louvain-la-Neuve Communiqué (2009). The Bologna Process 2020 - The European Higher Education Area in the new decade. EHEA Ministerial Conference, Leuven and Louvain-la-Neuve, 28-29 April 2009. Retrieved from: https://www.ehea.info/pid34363/ ministerial-declarations-and-communiques.html 


\begin{tabular}{|c|c|}
\hline $\begin{array}{l}\text { Declaration } \\
(2010)^{9}\end{array}$ & $\begin{array}{l}\text { HEd institutions have the necessary resources within a framework } \\
\text { established and overseen by public authorities. We are convinced that } \\
\text { HEd is a major driver for social and economic development and for } \\
\text { innovation in an increasingly knowledge-driven world. We shall } \\
\text { therefore increase our efforts on the social dimension in order to } \\
\text { provide equal opportunities to quality education, paying particular } \\
\text { attention to underrepresented groups }\end{array}$ \\
\hline $\begin{array}{l}\text { The Bucharest } \\
\text { Communiqué } \\
(2012)^{10}\end{array}$ & $\begin{array}{l}\text { Widening access to HEd is a precondition for societal progress and } \\
\text { economic development. We agree to adopt national measures for } \\
\text { widening overall access to quality HEd. We will work to raise } \\
\text { completion rates and ensure timely progression in HEd in all EHEA } \\
\text { countries. HEd should be an open process in which students develop } \\
\text { intellectual independence and personal self-assuredness alongside } \\
\text { disciplinary knowledge and skills }\end{array}$ \\
\hline $\begin{array}{l}\text { The Yerevan } \\
\text { Communiqué } \\
(2015)^{11}\end{array}$ & $\begin{array}{l}\text { We will enhance the social dimension of HEd, improve gender balance } \\
\text { and widen opportunities for access and completion, including } \\
\text { international mobility, for students from disadvantaged backgrounds }\end{array}$ \\
\hline $\begin{array}{l}\text { The Paris } \\
\text { Communiqué } \\
(2018)^{12}\end{array}$ & $\begin{array}{l}\text { We therefore commit to developing policies that encourage and } \\
\text { support HEIs to fulfil their social responsibility and contribute to a } \\
\text { more cohesive and inclusive society through enhancing intercultural } \\
\text { understanding, civic engagement and ethical awareness, as well as } \\
\text { ensuring equitable access to HEd }\end{array}$ \\
\hline
\end{tabular}

Thus, the basic documents of the Bologna Process declare a wide range of social guarantees from the governments of the Bologna countries. Systematization of the components of governments social commitments in higher education, as reflected in the above cited documents, makes it possible to summarize them in the following terms:

- ensuring the right to quality higher education for all (Berlin communiqué, Prague communiqué; Leuven /Louvain-la-Neuve communiqué, Bucharest communiqué, Budapest-Vienna Declaration, Yerevan communiqué, Paris communiqué);

- promoting intercultural understanding, political and religious tolerance, gender equality, democratic and civil rights in order to strengthen European and global citizenship and to lay the foundations for an inclusive society (Yerevan Communiqué, Paris Communiqué);

9 Budapest-Vienna Declaration on the European Higher Education Area (2010). Ministerial Conference in Budapest/Vienna, 10-12 March 2010. Retrieved from http://www.ehea.info/page-ministerial-declarations-and-communiques

${ }^{10}$ Bucharest Communiqué. (2012). Making the Most of Our Potential: Consolidating the European Higher Education Area. EHEA Ministerial Conference, Bucharest, 26-27 April, 2012. Retrieved from: https://www.ehea.info/pid34363/ministerial-declarations-andcommuniques.html

${ }^{11}$ Yerevan Communiqué (2015). EHEA Ministerial Conference. Yerevan, 14-15 May, 2015. Retrieved from http://www.ehea.info/page-ministerial-declarations-and-communiques

12 Paris Communiqué (2018). EHEA Ministerial Conference. Paris, May 25th 2018. Retrieved from http://www.ehea.info/page-ministerial-declarations-and-communiques 
- ensuring inclusiveness of the HEd, attracting new contingents of underrepresented social groups (London communiqué, Leuven /Louvain-laNeuve communiqué, Bucharest communiqué, Budapest-Viennese declaration, Declaration), refugees and immigrants (Yerevan Communiqué);

- providing students with adequate study and living conditions that allow them to complete their education within a specified period of time, regardless of the obstacles that may arise due to the social or economic background (Berlin Communique, Bergen Communique, London Communiqué, Leuven /Louvain-la-Neuve communiqué, Paris communique);

- improving the opportunity for all citizens, in accordance with their aspirations and abilities, to receive lifelong education, both within the framework of programs leading to higher education and within it (Berlin Communiqué, Yerevan Communiqué);

- providing the students with guidance and counselling services with a view to widening access (Bergen communique, Bucharest communique, Yerevan communique);

- development of a student-centered approach, in particular peer learning methods, as a means of providing greater access to quality education to diversified student contingents (Bucharest Communiqué, Yerevan Communiqué);

- ensuring the right of students to equal partnership participation in the management of higher education institutions, in resolving issues related to organization and content of the educational process (Prague Communiqué, Berlin Communiqué, Yerevan Communiqué);

- providing students, especially those from socially disadvantaged backgrounds, with financial assistance aimed at increasing access to higher education (Bergen Communiqué);

- providing academic and professional mobility opportunities for students, teachers, researchers through the development of a system of national grants, services, legislative recognition of periods of study and professional activity in a European context (Yerevan and Paris Communiqués);

- improving of employment opportunities and self-employment of university graduates (Yerevan Communiqué).

We emphasize that the basic requirement that defines the essence of the social dimension of the EHEA is formulated in London Communique (2007) "societal aspiration that the student body is entering, participating in and completing HEd at all levels should reflect the diversity of our populations". At the present stage, in the text of the Yerevan Communiqué (2015), the Bologna Community called for a broader understanding of the social dimension of higher education, formulating it as follows: "We will enhance the social dimension of HEd, improve gender balance and widen 
opportunities for access and completion, including international mobility, for students from disadvantaged backgrounds".

\section{Theoretical bases of the EHEA social dimension}

In substantiating the need for the social dimension of the EHEA, contemporary higher education theorists and educational policy-makers rely on a broad range of scientific approaches that are relevant to different fields of knowledge and ideological orientations:

- economic theories of public good. According to Paul Anthony Samuelson, the author of "The Pure Theory of Public Expenditure" (P. A. Samuelson, the Nobel laureate, established the notion of public/private, which is now dominant in economic policy), public goods are defined as one or both of non-rivalrous and non-excludable ${ }^{13}$. According to the American economist J. E. Stiglitz, the term "public good" means: 1) lack of competition in the consumption of goods, the overall availability of its simultaneous or consistent consumption, which does not reduce the amount of this benefit; 2) inability or difficulty of achieving such a situation where consumption of goods becomes the exclusive right of one person or an exclusive group of people ${ }^{14}$. The concept of "private good" in this context also includes two aspects: 1) good, the benefit of which is purely individual; 2) a good whose quantity is limited, so if consumed by one person, it cannot be consumed by another ${ }^{15}$. The modern theorist of higher education sociologist and philosopher Simon Marginson in his research work "Public/Private in Higher Education: A Synthesis of Economic and Political Approaches" attempts to combine the economic and political approaches to the analysis of the essence of higher education as a private and public good. Marginson insists that "together, the economic and political modes constitute a more explanatory and more instrumental framework for operationalizing the public/private distinction in higher education, than either the economic or political modes can provide alone. In sum, the political economic nature of higher education and research is determined by whether market competition is used for coordination, and/or whether activity is located or closely controlled in the state sector" ${ }^{\prime 16}$;

\footnotetext{
${ }^{13}$ Samuelson, P. (1954). The Pure Theory of Public Expenditure. Review of Economics and Statistics, 36 (4), P. 387.

${ }^{14}$ Stiglitz, J. E. (1983). Public goods in open economies with heterogeneous individuals. In J. F. Thisse, H. G. Zoller (Ed.), Locational analysis of public facilities. North-Holland Publishing Company, pp. 55-78.

${ }^{15}$ Ver Eecke, W. 2008. Ethical Dimensions of the Economy: Making Use of Hegel and the Concepts of Public and Merit Goods. Springer.

${ }^{16}$ Marginson, S. (2016). Private/public in higher education: A synthesis of economic and political approaches. Studies in Higher Education. Published online: http://dx.doi.org/10.1080/ 03075079.2016.1168797.
} 
- economic theory of social choice by James M. Buchanan and Gordon Tullock. The direct purpose of this theory is to analyze political mechanisms of the formation of macroeconomic decisions, but its provisions are applied within the framework of a neoliberal approach to educational reform strategies. In his Nobel lecture "The Constitution of Economic Policy", J. Buchanan formulated three leading conceptual frameworks on which his theory was built: methodological individualism, the concept of "homo economicus" and interpretation of politics as exchange. In their unity, these ideas represent a kind of "principles of social order" that guide human social activity, and in the context of the problematic conceptual principles underpinning the social dimension of Bologna reforms, explain neoliberal, i.e. market-based component of higher education reforms in EHEA ${ }^{17}$;

- sociological theories of the welfare state. According to Encyclopedia Britannica, "welfare state is as a form of government in which state protects and promotes economic and social well-being of citizens, based on the principles of equal opportunity, equitable distribution of wealth, and public responsibility for citizens unable to avail themselves of the minimum provisions for a good life" $"$. The notion of "welfare state" was first used in 1850 by Lorenz von Stein. He included in the list of functions of the state "maintenance of absolute equality in rights for all different social classes, for a separate private self-determining person through his power". The state, according to Stein, is obliged to promote economic and social progress of all its citizens, because ultimately development of one is a condition for development of another, and in this sense it is a social state. British sociologist T. H. Marshall described in the middle of the $20^{\text {th }}$ century the modern welfare state as a "distinctive combination of democracy, welfare, and capitalism" "19. In the spirit of neoliberal political ideology considers the social functions of the state American economist M. Friedman, who insists on the need to narrow its social functions. Educational policy in this context refers to the concept of denationalization of education, which was first formulated in the 1950s in M. Friedman's "Education and the Public Interest" $(1955)^{20}$, and later incorporated into M. Friedman's programmatic work "Capitalism and Freedom" (1962). According to M. Friedman, the need to reconsider the role of the state in education is a direct consequence

${ }^{17}$ Buchanan, J. M. (1986). Prize Lecture. The Constitution of Economic Policy. Lecture to the memory of Alfred Nobel. December 8, 1986. Retrieved from: https://www.nobelprize.org/ prizes/economic-sciences/1986/buchanan/lecture/

18 The welfare state. In: Encyclopedia Britannica Online. Retrieved from https:// Encyclopedia_Britannica_Online

${ }_{19}^{19}$ Marshall, T. H. (1950). Citizenship and Social Class: And Other Essays. Cambridge: University Press.

${ }^{20}$ Friedman, M. (1955). Education and the Public Interest. Ed. by Robert Solow. New Brunswick: Rutgers University Press. 
of the inconsistency of its powers in this field (financing and administration of education institutions) with the functions it assumes in other spheres of life in the conditions of the private enterprise economy and exchange ${ }^{21}$;

- sociological theories of the transition from "welfare state" to "competitive state", which became popular in Western sociology in the 80-90s of the twentieth century. The leader of this approach, the English sociologist A. Giddens substantiates the need to transform the social functions of the state, including in the field of education, by a number of factors, the most important of which are globalization and technological progress. All these factors, according to A. Giddens, make the old center-left political approaches counterproductive. The state, according to Giddens, is no longer able to give a full guarantee of the economic security and social protection of its citizens. It must flexibly combine the challenges of human capital development, civil society support and growing globalization of the business and financial community ${ }^{22}$;

- neoliberal political theories of education globalization of, which justify and explain such provisions as:

- erosion of the sovereignty of the nation-state and fullness of its powers in the field of social policy in general and education in particular;

- transfer of market competition mechanisms into the educational sphere;

- transfer of the social choice neo-institutional theory provisions to the sphere of education (choice of forms of education as one type of beneficial exchange);

- transfer of the idea of methodological individualism to education: a person as a free, rational, autonomous, self-interested (interested in maximizing his own good) individual - "homo economicus", who lives in the certain social organization, created to protect his natural rights and to promote a profitable exchange with others;

- development of ideas and mechanisms of "new managerialism", i.e. extension of the principles and mechanisms of management characteristic of the private business sphere to the social sphere, in particular to the sphere of higher education ${ }^{23}$;

- denationalization of the educational sphere, privatization of educational services, their "contractualization", "consumer-centrism"24;

\footnotetext{
${ }^{21}$ Friedman, M. (1962). Capitalism and freedom. Chicago: University of Chicago Press.

${ }^{22}$ Giddens, A. (1998). The Third Way: The renewal of social democracy. Cambridge: Polity Press.

${ }^{23}$ Shepherd, S. (2018) Managerialism: an ideal type. Studies in Higher Education, 43:9, 1668-1678, DOI: 10.1080/03075079.2017.1281239.

${ }^{24}$ Naidoo, R., Veer, E. (2011). The Consumerist Turn in Higher Education: Policy Aspirations and Outcomes. Journal of Marketing Management, 27 (11-12), 1142-1162.
} 
- "marketization of democracy". The notions of equality, justice, solidarity, which constitute the core values of a democratic society, are considered at the economic rather than the political level. A person is primarily a consumer, not a citizen;

- encouraging public-private partnerships in education as a factor in the development of social capital;

- "cultural reconstruction", "marketing of social consciousness", formation of "entrepreneurial society", which means, in the context of our reseasrch, transformation of education institutions into competing business institutions ${ }^{25}$;

- theories of sustainable development that have spread since report of Bruntland Commission to United Nations General Assembly "Our Common Future" (1987). According to the provisions of the report, mankind should strive for "development that meets the needs of the present without compromising the ability of future generations to meet their own needs" 26 . According to the UN Programme "Education for Sustainable Development", education must be revisited in light of a renewed vision of sustainable human and social development that is both equitable and viable. This vision of sustainability must take into consideration the social, environmental and economic dimensions of human development and various ways in which these relate to education: "An empowering education is one that builds the human resources we need to be productive, to continue to learn, to solve problems, to be creative, and to live together and with nature in peace and harmony. When nations ensure that such an education is accessible to all throughout their lives, a quiet revolution is set in motion: education becomes the engine of sustainable development and the key to a better world"27.

Summarizing the above-mentioned theories that have influenced and continue to influence development of theoretical and normative foundations of the Bologna process as a whole, and its social dimension in particular, we'd like to note the contradictory unity of the influences of neo-liberal and socio-democratic ideologies. Confirmation of our conclusion is seen in the documents of the Bergen Summit of Ministers of Education, which stated that social dimension of the Bologna Process is a constituent part of the EHEA and a necessary condition for the attractiveness and competitiveness of the EHEA. Therefore, the combination of competitiveness and social

${ }^{25}$ Peters, M. (2005). Neoliberalism. Encyclopedia of philosophy of education. Retrieved from: http://www.educacao.pro.br/.

${ }^{26}$ United Nations General Assembly (1987). Report of the world commission on environment and development: Our common future. Oslo, Norway.

27 Power, C. (2015). The Power of Education: Education for All, Development, Globalisation and UNESCO. London, Springer. 
justice is the contradictory unity that the social dimension of higher education reform in the EHEA is aimed at.

Next, we'll describe the official documents of international organizations, whose ideas served as a significant basis for the development of the ideology and methodology of constructing the phenomenon we are investigating - the social dimension of reforms in the EHEA. Following the logic of the genetic analysis we have already applied, we formulate a continuum of fundamental documents that underlie and influence formation and development of the social dimension of EHEA development. Such documents are:

- the United Nations' Universal Declaration of Human Rights, representing the unity and indivisibility of fundamental rights, including civil and political rights on the one hand and social and economic rights on the other hand, has been recognised since adoption in 1948;

- The European Convention on Human Rights, guaranteeing civil and political rights, was adopted by Council of Europe in 1950;

- The European Social Charter (1961), guaranteeing social and economic rights (its Additional Protocol of 1988 and the Revised Charter, adopted in 1996). The European Social Charter is a Council of Europe treaty that guarantees a broad range of everyday human rights related to employment, housing, health, education, social protection and welfare. The Charter lays specific emphasis on the protection of vulnerable persons such as elderly people, children, people with disabilities and migrants. It requires that enjoyment of the above-mentioned rights be guaranteed without discrimination. No other legal instrument at pan-European level can provide such an extensive and complete protection of social rights as that provided by the Charter, which also serves as a point of reference in European Union law; most of the social rights in the EU Charter of Fundamental Rights are based on the relevant articles of the Charter. The Charter is a kind of the Social Constitution of Europe and represents an essential component of the continent's human rights architecture ${ }^{28}$;

- The European Pillar of Social Rights (2017) - the EU document, which marks a turning point in the development of the social dimension of European integration. The Pillar is about delivering new and more effective rights for EU citizens. It builds upon 20 key principles, structured around three categories: 1) equal opportunities and access to the labour market; 2) fair working conditions; 3 ) social protection and inclusion. It is worth noting that the first of the identified 20 principles pertaining to the category "equal opportunities and access to the

${ }^{28}$ European Social Charter and European Convention on Human Rights. Retrieved from: https://www.coe.int/en/web/european-social-charter/-european-social-charter-and-europeanconvention-on-human-rights 
labour market" refers to education and is defined as education, training and lifelong learning. The principle declares: Everyone has the right to quality and inclusive education, training and life-long learning in order to maintain and acquire skills that enable them to participate fully in society and manage successfully transitions in the labour market ${ }^{29}$.

\section{The organizational bases of the EHEA social dimension}

The Bologna is a process of large-scale reforms in the sphere of higher education, agreed on a voluntary basis by the governments of 47 countries. The main political mechanism for implementation of the Bologna Process is the so-called Open Method of Coordination (OMC) including such components:

- defining common goals of activity and cooperation in their implementation in accordance with the agreed program and timetable;

- organizing cooperation and peer learning for partners to identify best practices for further dissemination;

- monitoring implementation of joint programs through a system of indicators and benchmarks;

- drawing up information and analytical reports in accordance with clearly defined indicators and benchmarks ${ }^{30}$.

Therefore, based on the logic of using the OMC mechanisms we'll analyze, how indicators for implementation of the EHEA social dimension are developed and applied, and which of the Bologna actors are most actively involved in this process.

The practice of developing indicators of the higher education social dimension has a long history in the EU. It begins with a project called "EUROSTUDENT - Social and Economic Conditions of Student Life in Europe", funded by the Erasmus and supported by the governments of the leading EU Member States. In turn, this project builds on the experience gained by the DSW (Deutsches Studentenwerk) with its social surveys on the economic and social situation of students in Germany, which it has regularly carried out since 1951 . In 1997, that is, before the start of the Bologna Process, the results of the EUROSTUDENT pilot project, which at the time were carried out with cooperation of student organizations and governments of four European countries (Germany, France, Italy and Austria), were published. This European social survey is aimed at collecting data on the living conditions of students in various European countries

${ }^{29}$ The European Pillar of Social Rights. Retrieved from: https://ec.europa.eu/commission/ priorities/deeper-and-fairer-economic-and-monetary-union/european-pillar-social-rights_en

${ }^{30}$ Sbruieva, A. (2014). Open Method of Coordination: an innovative mechanism for governing the processes of European integration in the sphere of higher education. Pedagogical sciences: theory, history, innovative technologies, 6 (40), 282-294. 
which will allow longer-term comparisons to be made. The data and comparisons were to become the basis for relevant socio-political decisionmaking in the education sector, in particular, on the promotion of social and regional mobility.

The report (EUROSTUDENT pilot project) presents data on 33 indicators of social and economic conditions of student life in Europe, grouped into 5 groups: personal student financing; social background; state support; international mobility; housing ${ }^{31}$. Together, these indicators compiled Synopsis of Indicators, which was further developed and refined. Already in 2000, at the time of the EHEA's construction, the following EUROSTUDENT project report was published, presenting and analyzing data on the economic and social situation of students in $8 \mathrm{EU}$ countries. Synopsis-2000 included 9 indicator groups: 1) demographic characteristics; 2 ) access to higher education; 3) study performance; 4) social make-up of the student body; 5) accommodation; 6) funding and state assistance; 7) living expenses - student spending; 8) student employment and time budget; 9) internationalisation ${ }^{32}$. In subsequent years, EUROSTUDENT Reports were published regularly every 3-4 years $(2003,2005,2008,2012$, $2016^{33}$ ). The latest of the published reports - "EUROSTUDENT VI 20162018 " contains data on 28 countries, including some countries-associated members of the EU. Unfortunately, Ukraine has only once been submitted to the project reports in 2015, and partly because national data were not provided for all indicators. In general, the EUROSTUDENT project materials represent the most representative database and analytical conclusions on the socio-economic status of European students used in the development and implementation of the social dimension of the Bologna reforms and development of the EHEA.

In addition to the EUROSTUDENT project, which has been active for several decades, certain information and analytical resources on the development of the EHEA social dimension may be borrowed from the Project "Peer Learning Initiative for the Social Dimension (PL4SD)" (20122015) funded by the European Commission through the Lifelong Learning Programme (Erasmus Multilateral projects). The objective of the PL4SD

${ }^{31}$ EURO STUDENT Report (1997). Social and Economic Conditions of Student Life. Synopsis of Indicators. Austria, France, Germany, Italy. Pilot-Project of the Deutsches Studentenwerk (DSW). Retrieved from: https://www.eurostudent.eu/download_files/ documents/eurostududent_pilot_project.pdf

${ }^{32}$ EURO STUDENT (2000). Social and economic conditions of student life in Europe 2000. Synopsis of Indicators and National Profiles for Austria. Belgium (Flemish Community), Belgium (Wallonia-Brussels Community), Finland, France, Germany, Ireland, Italy and The Netherlands. HIS Hochschul-Informations-System, Hannover 2002, Germany.

33 EUROSTUDENT. Publications. EUROSTUDENT round. Retrieved from: https://www.eurostudent.eu/publications\#result_anker 
project was to provide policy-makers and practitioners with resources to develop effective measures for ensuring the social dimension of the European Higher Education Area. Specific objectives of the project were: to ensure transparency in current developments, allowing the actors in the field to assess their own performance as well as to monitor their progress towards reaching the targets set within the EHEA; to stimulate international exchange and debate on policy measures and to add more creativity to tackling difficulties within the field of the social dimension in higher education; to enable peer learning and to ease implementation of policy measures by other countries, higher education institutions and students' organisations; to structure the information and to collect relevant reports and research on social dimension policies; to provide a solid basis for further research ${ }^{34}$.

It should be noted that while implementation of the PL4SD project has drawn the attention of the Bologna member states to the need to fulfill their social obligations in the field of higher education, the EUROSTUDENT project materials and information resources are much more useful for EHEA development researchers as an information and analytical resource.

Next we'll focus on the activities of the collective actors of the Bologna Process in promoting the EHEA social dimension. Traditionally, analysis of the activities of the Bologna actors in realization of the reform tasks takes into account the specific interests of their different types, above all supranational political organizations (Bologna Follow-Up Group (BFUG), European Commission (EC)) and professional organizations (ENQA, EUA, ESU, EURASHE, EQAR, EQAF, Education International, BUSINESSEUROPE). All of these entities have been cooperating on a systematic basis since the start of the Bologna Process (E-4 Group: ENQA, EUA, ESU, EURASHE), or have joined it during its development (EQAR, EQAF, Education International, USINESSEUROPE). An analysis of the wide range of Bologna process documents shows that all these organizations are active and significant in the development and implementation of the social dimension of reform. However, we consider it fair to highlight in the context of our study, first and foremost, the role of student organizations subjects of the Bologna Process.

At the beginning of this study, we have already emphasized the special role of ESIB in building social priorities of the change process. It should be noted that the student body has been and remains an important driver of the Bologna Processes, which has repeatedly stated its dissatisfaction with the practice of educational reforms in different countries ("The black book of the

\footnotetext{
${ }^{34}$ Peer Learning Initiative for the Social Dimension (PL4SD). https://en.iro.hr/2018/02/19/pl4sdpeer-learning-initiative-for-the-social-dimension-p14sd/
} 
Bologna Process", 2005) and made constructive proposals for the further development of the Bologna changes (Bologna With Student Eyes (2012, $2015,2018)$ ). We cite only the latest publication, prepared for the BFUG Paris Summit, which is the conclusion of the student organization on the state of the problem under discussion in EHEA: "The social dimension of higher education is seen a high priority only in very few national contexts. Across all Europe, there has been a little improvement in the general acknowledgement of the importance of working on social dimension measures, but no substantial step forward has been taken. For instance, financial support, the most common way of supporting students, especially those with a low socio-economic background, that are still the biggest underrepresented group among students, is still far from being accessible for all, or at least for all that really need it to complete their education. Moreover, the students are particularly concerned about the lack of services for disabled student and mental health support" ${ }^{35}$. As we can conclude from the abobe cited statement, students are clearly disappointed with the results in the sphere of student social support. However, the documents analyzed below indicate that they are determined to go step by step towards achieving the stated goal of providing quality higher education for all.

We emphasize that activities and publications of ESU relate both to issues of national and international education policy and organizational development of the EHEA (2018 Introduction to ESU's policies in higher education $^{36}$ ), and to the philosophy and didactics of higher education, in particular development of the idea of student-centered learning. A number of ESU policy documents focus exclusively on the implementation of the social dimension of higher education. In particular, "Policy Paper on Social Dimension" (2015) addresses the issues of facets of social dimension and a system of indicators through which the governments of the Bologna Member States can monitor provision of quality education for all. In particular, ESU distinguishes the following facets of the phenomenon that is the subject of our study: 1) access to higher education; 2) social mobility; 3) affordability; 4) lifelong learning; 5) early stage interventions; 6) equality and equity; 7) diversity; 8) active anti-discrimination measures; 8) student centered learning; 9) accessibility: 10) student support services; 11) support during the studies and completion rates; 12) active citizenship and democratic development; 13) science and society. The document identifies also the roles and responsibilities of stakeholders (students, ESU and student organizations, higher education institutions and their joint fora, national

\footnotetext{
${ }^{35}$ ESU (2018). Bologna with Student Eyes 2018: The final countdown. Brussels, May 2018 by European Students' Union.

${ }^{36}$ ESU (2018). Introduction to ESU's policies in higher education. Brussels, European Students' Union.
} 
policy, EHEA, the Bologna Process and the European Union, UNESCO and international organizations) $)^{37}$. The latest ESU's Policy Document - "Social Dimension Policy Paper 2019", which was published in preparation for the Bologna Education Ministers' Anniversary Conference in 2020, is the next step in identifying indicators for implementing the EHEA social dimension. Such indicators, according to ESU experts, should be: 1) early stage interventions; 2) recognition (both for formal and non-formal prior learning, and for other previously acquired competences); 3) fair \& supportive environments for staff; 4) student support systems; 5) direct costs \& tuition fees; 6) grants \& loans; 7) indirect costs: housing \& transportation; 8) mental health \& support services; 9) flexible learning pathways; 10) students' employment; 11) student centered learning; 12) language; 13) lifelong learning ${ }^{38}$. The most significant change in the system of indicators proposed and analyzed by students is the focus on "fair \& supportive environments for staff", which students have attributed to both professional development of teachers and their financial support.

We'd like to emphasize once again that student organizations are the most interested and therefore the most active and persistent in implementing the social dimension of higher education in the context of the Bologna Process.

At the same time, the greatest administrative burden and responsibility for implementing reform strategies rests on the shoulders of higher education institutions participating in the Bologna process. Their collective representative in the administration of the Bologna Process is the Bologna Follow-Up Group (BFUG), within which the Advisory Group on Social Dimension (AG 1) operates during its various stages of BFUG existence.

Like all other BFUG entities, AG 1 applies the Open Method of Coordination mechanisms, which, as noted above, identify common goals and cooperate in their implementation; organizing peer learning for partners to identify best practices for further dissemination; monitoring implementation of joint programs through a system of indicators and benchmarks; drawing up information and analytical reports in accordance with clearly defined indicators and benchmarks. The most important aspect of the activities of the Advisory Group on Social Dimension in today's context is preparation of the document "Vision for the future "Principles and Guidelines for Social Dimension (PAG)" Accompanied with the SWOT for achieving the vision" (Zagreb, MSE, 19.02.2019). The Advisory Group formulated its Vision for the future PAGs:

${ }^{37}$ ESU (2015). Policy Paper on Social Dimension. European Students' Union, Brussels, Belgium.

${ }^{38}$ ESU (2019). Social Dimension Policy Paper 2019. European Students' Union, Brussels, Belgium. 
- PAGs should be specific to different target groups (for example: specific PAGs for Governments, HEIs, students etc.);

- PAGs should be structured in a manner that allow comparability Each PAG should be drafted in a manner that allows to have an overarching aim, and then clear indicators which can be monitored;

- HEIs should see PAGs as a central goal. This would mean that these PAGs should be based on rational arguments, and ideally would be such as to allow support by other entities, including governments;

- PAGs should serve as a template for national strategies. Ideally this would also mean that once these national strategies are adopted, then HEIs will need to report on progress;

- PAGs should keep in mind several policy areas and ensure synergies between them. These policy areas include: living conditions, academic considerations (recognition), student socialization (ex. Mentors) ${ }^{39}$.

We are sure that PAGs will serve as a kind of analogue of the "Standards and Guidelines for Quality Assurance in the European Higher Education Area", first developed in the framework of the Bologna Process in 2005 and refined in the context of student-centered ideas in 2015. We understand that adherence to the principles (Principles for Social Dimension of higher education) and adherence to standards (Standards for quality assurance in higher education) are not identical in terms of mandatory requirements for their fulfillment. However, we are convinced that defining the principles and developing recommendations for their adherence to be adopted at the Anniversary Conference of Ministers in Bologna in 2020 will be the first step towards developing standards for the social dimension of higher education that will make them compulsory for the entire Bologna community.

\section{CONCLUSIONS}

1. Diachronous and comparative analysis of the Bologna basic documents in the context of the research problem has made it possible to identify tendencies in the interpretation of the social dimension of higher education during the EHEA development process. It should be noted that the documents identify first of all the strategic priorities, which include statements of support for the idea that higher education should be considered a public good and is and will remain a public responsibility (The Prague Communiqué, 2001), that the social dimension of the Bologna Process is a constituent part of the EHEA and a necessary condition for the attractiveness

39 BFUG AG 1. (2019). Vision for the future "Principles and Guidelines for Social Dimension (PAG)" Accompanied with the SWOT for achieving the vision" Zagreb, MSE, 19.02.2019 
and competitiveness of the EHEA; that making quality HEd equally accessible to all is an undisputed priority of EHEA (The Bergen Communique (2005). The major tendency of the development of the regulatory framework for the social dimension of the EHEA is specification and extention of the States obligations to ensure the social dimension of higher education. Therefore, it has been clarified to which underrepresented groups the support of the state should be directed (socially disadvantaged groups, gender groups, racial and national minorities groups), what student problems require state support (access, appropriate studying and living conditions, completion of the studies, international mobility); what kind of state support will be given to students (widening overall access, providing adequate student services, creating more flexible learning pathways, improving the learning environment, removing all barriers to study, creating the appropriate economic conditions for students etc.).

2 . The study systematized and summarized the theoretical foundations of the EHEA (economic theories of public good, economic theories of social choice, sociological theories of the welfare state, sociological theories of the transition from "welfare state" to "competitive state", neoliberal political theories of globalization of education, theories of sustainable development, the idea of social Europe) that explain the twofold nature of change in the context of Bologna Procrss. On the one hand, it is the focus of reforms on meeting the needs of the region's economic development and global competition with other geopolitical regions, which prioritises the tasks of quality assurance, competitiveness and global attractiveness of European higher education. On the other hand, the EHEA strategy fulfills the requirements of European society for the realization of Social Europe's ideas, i.e. realization of democratic values of equal rights and self-realization of each individual. The trend towards further development of the EHEA is to find consensus on the challenges of enhancing competitiveness and social justice in higher education.

3. The study shows that the leading mechanism for implementing the EHEA social dimension is the Open Method of Coordination, which means definition of common goals of the Bologna collective actors, organization of cooperation and mutual learning of partners, monitoring implementation of joint programs through systems of indicators and benchmarks, preparation of information and analytical reports. In line with the OMC logic, the practice of the activities of the collective actors of the Bologna Process in developing a system of indicators of the social dimension of European higher education is characterized by means of comparative analysis of the EUROSTUDENT project reports (1997-2016) and ESU policy documents (Policy Paper on Social Dimension (2015-2018)).

Analysis of the activities of the Bologna Advisory Group on Social Dimension (AG 1) has made it possible to state that the most important 
result of AG 1's activity today is development of the document "Vision for the future "Principles and Guidelines for Social Dimension (PAG) "Accompanied by the SWOT for Achieving the Vision" (Zagreb, MSE, 02/19/2019). We believe that approval of the Principles and Guidelines for Social Dimension (PAG) at the Anniversary Conference of Ministers in Bologna in 2020 will speak of a trend towards development of standards for the social dimension of the EHEA.

\section{SUMMARY}

The study describes the tendencies of development of normative, theoretical and organizational bases of the social dimension of the European Higher Education Area. It is found out that the tendency of development of the normative bases of the EHEA social dimension was the gradual specification of the reference groups, content and instruments that make up the responsibility of the states in the field of higher education. Elucidation of theoretical foundations made it possible to explain the twofold nature of the EHEA, its focus on realization of economic and social priorities of the region. The discovery of the organizational bases of the phenomenon under consideration involved clarifying the nature of application of the Open Method of Coordination in the activities of leading stakeholders in the sphere of European higher education.

\section{REFERENCES}

1. Sbruieva, A. (2014). Open Method of Coordination: an innovative mechanism for governing the processes of European integration in the sphere of higher education. Pedagogical sciences: theory, history, innovative technologies, 6 (40), 282-294.

2. Berlin Communiqué (2003). Realizing the European Higher Education Area. EHEA Ministerial Conference, Berlin, 19, September 2003. Retrieved from: https:// www.ehea.info/page-ministerial-declarations-andcommuniques.

3. Bologna Follow-Up Group (BFUG). Advisory Group on Social Dimension (AG 1). (2019). Vision for the future "Principles and Guidelines for Social Dimension (PAG)" Accompanied with the SWOT for achieving the vision". Zagreb, MSE, 19.02.2019.

4. Buchanan, J. M. (1986). Prize Lecture. The Constitution of Economic Policy. Lecture to the memory of Alfred Nobel. December 8, 1986. Retrieved from: https://www.nobelprize.org/prizes/economic-sciences/1986/buchanan/ lecture/.

5. Bucharest Communiqué (2012). Making the Most of Our Potential: Consolidating the European Higher Education Area. EHEA Ministerial Conference, Bucharest, 26-27 April, 2012. Retrieved from: 
https://www.ehea.info/pid34363/ministerial-declarations-andcommuniques.html.

6. Budapest-Vienna Declaration on the European Higher Education Area (2010) Ministerial Conference in Budapest/Vienna, 10-12 March 2010. Retrieved from: http://www.ehea.info/page-ministerial-declarations-andcommuniques.

7. ESIB (2001). Student Göteborg Declaration (25 March 2001). The Student Göteborg Convention, 22nd to the 25th of March 2001.

8. ESU (2015a). Overview on student-centered learning in higher education in Europe: Research study. Brussels, European Students' Union, Erasmus (Lifelong Learning programme).

9. ESU (2015b). Policy Paper on Social Dimension. European Students' Union, Brussels, Belgium.

10. ESU (2018a). Bologna with Student Eyes 2018: The final countdown. Brussels, May 2018 by European Students' Union.

11. ESU (2018b). Introduction to ESU's policies in higher education. Brussels, European Students' Union.

12. ESU (2019). Social Dimension Policy Paper 2019. European Students' Union, Brussels, Belgium.

13. EURO STUDENT Report (1997). Social and Economic Conditions of Student Life. Synopsis of Indicators. Austria, France, Germany, Italy. Pilot-Project of the Deutsches Studentenwerk (DSW). Retrieved from: https://www.eurostudent.eu/download_files/documents/eurostududent_pilot_ project.pdf.

14. EURO STUDENT (2000). Social and economic conditions of student life in Europe 2000. Synopsis of Indicators and National Profiles for Austria, Belgium (Flemish Community). Belgium (Wallonia-Brussels Community), Finland, France, Germany, Ireland, Italy and The Netherlands. HIS Hochschul-Informations-System, Hannover 2002, Germany. Retrieved from: https://www.eurostudent.eu/download_files/documents/ eurostududent_2000_project.pdf.

15. European Social Charter and European Convention on Human Rights. Retrieved from: https://www.coe.int/en/web/european-socialcharter/-european-social-charter-and-european-convention-on-human-rights

16. EUROSTUDENT. Publications. EUROSTUDENT round. https://www.eurostudent.eu/publications\#result_anker.

17. Friedman, M. (1955). Education and the Public Interest. Ed. by Robert Solow. New Brunswick: Rutgers University Press.

18. Friedman, M. (1962). Capitalism and freedom. Chicago: University of Chicago Press.

19. Giddens, A. (1998). The Third Way: The renewal of social democracy. Cambridge: Polity Press. 
20. Klemenčič, M. (2012). How ESIB got into the Bologna Process. In ESU turns 30! Fighting for student rights since 1982. Brussels: ESU, pp. 17-28.

21. Leuven and Louvain-la-Neuve Communiqué (2009). The Bologna Process 2020 - The European Higher Education Area in the new decade. EHEA Ministerial Conference, Leuven and Louvain-la-Neuve, 28-29 April 2009. Retrieved from: https://www.ehea.info/pid34363/ministerialdeclarations-and-communiques.html.

22. Marginson, S. (2016). Private/public in higher education: A synthesis of economic and political approaches. Studies in Higher Education. Retrieved from: http://dx.doi.org/10.1080/03075079.2016.1168797

23. Marshall, T. H. (1950). Citizenship and Social Class: And Other Essays. Cambridge: University Press.

24. Naidoo, R., Veer, E. (2011). The Consumerist Turn in Higher Education: Policy Aspirations and Outcomes. Journal of Marketing Management, 27 (11-12), 1142-1162.

25. Paris Communiqué (2018). EHEA Ministerial Conference. Paris, 25th May 2018. Retrieved from: http://www.ehea.info/page-ministerialdeclarations-and-communiques.

26. Peer Learning Initiative for the Social Dimension (PL4SD). https://en.iro.hr/2018/02/19/pl4sd-peer-learning-initiative-for-the-socialdimension-pl4sd/.

27. Peters, M. (2005). Neoliberalism. Encyclopedia of philosophy of education. Retrieved from: http://www.educacao.pro.br/

28. Power, C. (2015). The Power of Education: Education for All, Development, Globalisation and UNESCO. London, Springer.

29. Samuelson, P. (1954). The Pure Theory of Public Expenditure. Review of Economics and Statistics, 36 (4), 387.

30. Shepherd, S. (2018). Managerialism: an ideal type. Studies in Higher Education, 43:9, 1668-1678. DOI: 10.1080/03075079.2017.1281239

31. Stiglitz, J. E. (1983). Public goods in open economies with heterogeneous individuals. In J. F. Thisse, H. G. Zoller (Eds.), Locational analysis of public facilities, pp. 55-78. North-Holland Publishing Company.

32. The Bergen Communiqué. (2005). The European Higher Education Area - Achieving the Goals. Communique of the Conference of European Ministers Responsible for Higher Education. Bergen, 19-20 May 2005. Retrieved from: https:// www.ehea.info/page-ministerial-declarations-andcommuniques

33.The European Pillar of Social Rights. https://ec.europa.eu/ commission/priorities/deeper-and-fairer-economic-and-monetaryunion/european-pillar-social-rights_en.

34. The London Communiqué. (2007). Towards the European Higher Education Area: responding to challenges in a globalised world. EHEA 
Ministerial Conference, London, 18-19 May, 2007. Retrieved from https:// www.ehea.info/page-ministerial-declarations-and-communiques

35. The welfare state. In Encyclopedia Britannica Online. Retrieved from: https:// Encyclopedia_Britannica_Online.

36. Towards the European Higher Education Area. Communique of the meeting of European Ministers in charge of Higher Education in Prague on 19th May 2001. Retrieved from: www.ehea.info/Uploads/ Declarations/PRAGUE_COMMUNIQUÉ.pdf

37. United Nations General Assembly (1987). Report of the world commission on environment and development: Our common future. Oslo, Norway.

38. Ver Eecke, W. (2008). Ethical Dimensions of the Economy: Making Use of Hegel and the Concepts of Public and Merit Goods. Springer.

39. Yerevan Communiqué (2015). EHEA Ministerial Conference. Yerevan, 14-15 May 2015. Retrieved from http://www.ehea.info/pageministerial-declarations-and-communiques.

40.Zgaga, P. (2015). The social dimension in the European Higher Education Area. In Baranović, B. (Ed.) Koji srednješkolci namjeravaju studirati? Pristup visokom obrazovanju i odabir studija. Zagreb: Institut za društvena istraživanja/ pp. 211-233.

Information about the author: Alina Sbruieva, Professor, Doctor of Pedagogical Sciences, Head of the Chair of Pedagogy Sumy State Pedagogical University named after A. S. Makarenko

87, Romenska str., Sumy, 40002, Ukraine ORCID ID: orcid.org/0000-0002-1910-0138 